\title{
Early detection of active Human Cytomegalovirus infection after
} living-donor liver transplantation

Mohamed Anies Rizk ${ }^{1}$, Salah Abd Elfatah Agha ${ }^{2}$, Maysaa El Sayed Zaki ${ }^{2}, \quad \begin{aligned} & 3 \\ & 4\end{aligned}$ Noha Badr El-Deen El-Mashad ${ }^{2}$, Mohamed Mahmoud Fahmy El-Saadany ${ }^{3}$, 5

1: Clinical Microbiology Unit, Clinical Pathology Department, Faculty of Medicine, 7 Mansoura University, Egypt. (Corresponding author e. mail: 8 muhamedanies@yahoo.com )

2: Clinical Pathology Department, Faculty of Medicine, Mansoura University, Egypt. 10

3: Internal Medicine Department, Faculty of Medicine, Mansoura University, Egypt. 11

Abstract

Human cytomegalovirus (HCMV) is a member of the beta herpes virinae. It is one of the most important virus in transplantation. It has direct and indirect impact 16 on liver transplant recipient outcome. We aimed to diagnose early active HCMV 17 infection in living donor liver transplant (LDLT) recipients. Also, to correlate the 18 associated clinical and laboratory findings with HCMV infection. Here, we 19 investigate 76 LDLT recipients for early detection of active HCMV infection in a 20 period of 1-6 months after liver transplantation upon their suggested clinical data. 21 These samples were collected in the period from 4/2013 to $12 / 2015$ at 22 Gastroenterology center, Mansoura University. They were 68 males and 8 females. 23 HCMV infection diagnosed by ELISA (Ig M, Ig G) and real time PCR. Seventy-four 24 patients were $\operatorname{IgG}$ seropositive recipient. Three patients (3.9\%) were positive IgM. 25 Ten samples from 76 patients $(13.2 \%)$ were positive by real-time polymerase chain 26 reaction (PCR). In this study, we concluded that, LDLT recipients are at high risk of 27 HCMV infection (13.2\%) and the most suitable method for HCMV detection was 28 PCR.

Key words: $\quad 30$

- HCMV: Human Cytomegalovirus 31

- LDLT: Living-donor liver transplantation 32

- PCR: Polymerase Chain Reaction. 33

- ELISA: Enzyme linked Immunosorbent Assay 34 


\section{Introduction}

Opportunistic viral infections are common after liver transplantation. The herpes

virus infections are common after transplantation; Human cytomegalovirus (HCMV)

is most important virus of this group ${ }^{(1)}$ HCMV belongs to the beta herpes virus

The great seroprevalence and early acquisition of the virus have been associated

with lower socioeconomic circumstances, developing countries and over crowded populations ${ }^{(3) .}$ HCMV infects $60 \%-100 \%$ of humans, with primary HCMV infection occurring most commonly during the first two decades of life. In immunocompetent individuals, the infected individuals are mostly asymptomatic or may present with a benign febrile infectious mononucleosis-like illness ${ }^{(4)}$. HCMV infection occur in the majority of solid organ transplant patients, primarily in the first months when immunosuppression is most intense, HCMV disease incidence ranges from $10 \%$ to $50 \%(4)$.

Liver transplant recipients are at a higher risk of HCMV infection, especially those who did not have HCMV infection until they receive a latently infected organ range of immunomodulatory and vascular effects, referred to as indirect effects ${ }^{(6) .} \quad 59$

The aim of this study was to detect the incidence of HCMV infections in living- 61 donor liver transplantation recipients by ELISA and real time PCR. Also, to correlate 62 the laboratory findings with HCMV infections. 63

\section{Materials and Methods}

\section{Subjects}

This study was conducted on 76 living-donor liver transplant (LDLT) recipients 
consent was obtained from patients. They were investigated for detection HCMV 71 infections in a period up to 6 months after liver transplantation according to suspected $\quad 72$ clinical symptoms (e.g. fever, hepatitis, pneumonitis, urinary tract infections, 73 gastroenteritis such as diarrhea and vomiting) (Group I). In addition, 10 living-donor 74 liver transplant recipients of matched age and sex, who did not complain of any 75 symptoms suggestive of HCMV, were included as a control group (Group II). 76

\section{Methods}

I. For the patients and control group, the followings were done:

- $\quad$ History was taken, thorough clinical examination, to detect suspected cases ,e.g. 80 (fever , gastroenteritis as; diarrhea, vomiting, urinary tract infections, 81 pneumonitis).

- Routine laboratory investigations as; Liver function tests (Bilirubin, Albumin, 83 ALT, AST, ALP and GGT), kidney function tests (creatinine, urea and uric acid), C-reactive protein (CRP) were carried out using (Cobas Integra 800, 85 Roche Diagnostics), and complete blood picture (CBC) was carried out using 86 (Sysmex 1000).

\section{Detection of HCMV antibodies (IgM, IgG) by ELISA}

II. a. Detection of HCMV IgM and IgG: (DRG International, Inc., USA)

Blood samples were collected in a sterile vaccutainers and the serum was separated and stored at $-20{ }^{\circ} \mathrm{C}$ until processing.

\section{II. b. Molecular detection of HCMV DNA by real-time PCR:}

Blood samples were collected in a sterile vaccutainers and the serum was separated and stored at $-20{ }^{\circ} \mathrm{C}$ until processing. 
Principle:

HCMV detection by the polymerase chain reaction (PCR) is based on the amplification of specific regions of HCMV genome. In real-time PCR, the amplified product is detected via fluorescent dyes. These are usually linked to oligonucleotide probes, which bind specifically to the amplified product.

\section{Amplification and detection:}

Amplification and detection performed using the STRATAGENE (Applied Biosystems Inc., Foster City, CA)

Thermal profile

Initially precycling denaturation and then Taq activation achieved at $95{ }^{\circ} \mathrm{C}$ for 10 minutes. Then 45 cycles of denaturation at $95{ }^{\circ} \mathrm{C}$ for 15 seconds, annealing and extension at $55{ }^{\circ} \mathrm{C}$ for 1 minute (Table I).

The results were then quantified using HCMV DNA at predetermined concentrations provided by the manufacturer or from standard curve (Figure I).

\section{Statistical analysis}

Data analyzed and processed with SPSS software (Statistical Product and quantitative variables done with Pearson's correlation coefficient or Spearman's rank

\section{Results}

The age and sex distribution in the studied patients ranged from 29 to 63 years old with a mean of $51.14 \pm 7.116$. They were 68 males and 8 females. The mean age of the control group (group II) was $(49.90 \pm 6.74)$ (Table 2). The mean time for occurrence of active HCMV infections occurred during the second post-transplant 
The clinical data of the studied patients. Fever was the most common 136 presentation in all studied cases $(69.7 \%)$ followed by hepatitis $(56.6 \%)$, gastroenteritis $(42.1 \%)$, pneumonitis $(5.3 \%)$. There was a significant difference between patients versus control group regarding to gastroenteritis, hepatitis and fever $(\mathrm{p}=0.011,0.001$ and $<0.001$ respectively) (Table 4).

HCMV detection by different methods in the studied cases: out of 76 patients, $74(97.45 \%)$ were IgG seropositive, 3 (3.9\%) were positive for IgM and 10 (13.2\%) were positive by real-time PCR. They were compared to control subjects and there was no significant difference as regard IgG. On the other hand, there was significant difference as regards IgM and PCR (Table 5).

The sensitivity, specificity, positive and negative predictive values of ELISA IgM for HCMV in comparison to real-time PCR as the reference standard. Both techniques gave positive results in two cases and negative in 65 patients. The 148 sensitivity, specificity, positive predictive value and negative predictive value of ELISA IgM for HCMV were $(20.0 \%, 98.5 \%, 66.7 \%$ and $89.0 \%$ respectively). Prevalence of positive HCMV in studied group I= 13.2\% (Table 6).

Clinical data of HCMV in studied group I $(n=76)$. Gastroenteritis, hepatitis

and fever showed significant differences between positive cases versus control subjects ( $\mathrm{p}=0.033,0.003,0.001$ respectively). Pneumonitis did not differ significantly between positive cases and control subjects (Table 7).

Clinical indications did not show significant differences between patients with positive HCMV infection versus those with negative HCMV infection and versus control subjects $(\mathrm{p}>0.05)$ (Table 8).

The relation between HCMV infection and laboratory data was increased between group I and control group (group II) ( $\mathrm{p}=0.002,0.001,0.009$ respectively), increased ALP and glucose showed marginally significant differences $(p=0.093$, 0.071 respectively), increased CRP showed a significant difference $(\mathrm{p}=0.038)$. Mild reduction of hemoglobin concentration and mild elevation of INR showed marginally significance ( $\mathrm{p}=0.0503,0.066$ respectively) (Table 9).

The relationship of post-transplant complications with active HCMV in-group 
versus $24.2 \% \%$ in positive versus negative HCMV), $(\mathrm{p}=0.128)$. No significant

differences were found in recurrent HCC, biliary complications, other infections and

\section{Discussion}

The age of the studied patients ranged from 29 to 63 years with a mean $51.14 \pm 7.116$ years. They were $68(89.47 \%)$ males and $8(10.52 \%)$ females. We assays. Out of 76 patients, $74(97.36 \%)$ patients were $\operatorname{IgG}$ seropositive and three patients (3.9\%) were HCMV IgM seropositive. Real-time PCR was positive in 10 out of 76 patients (13.2\%). The high prevalence of HCMV IgG antibodies in this study indicates that the incidence of HCMV infection is high in Egypt and this may be attributed to the poor socioeconomic status and hygienic practices.

Razonable and Pya, (2003) showed in their study that the incidence of HCMV infection ranges from $10 \%$ to $50 \%$ following solid organ transplantation ${ }^{(4) .}$ Jain et al., (2005) showed that, the incidence of HCMV infection was $14 \%$ after liver 186 transplantation (7). In accordance Wadhawan et al., (2012) reported that HCMV reactivation was in $13 \%$ after LDLT, also, Katsolis et al., (2013) showed that HCMV infection was in $40 \%$ and disease was in $19 \%{ }^{(8,9)}$. In a study by Garbinoa et al. (2005), they reported that infection episodes among the 78 out of 98 patients (80\%), $44 \%$ were due to viral infections and HCMV infection was present in $29 \%$ of these infections. Thirty-four patients $(68 \%)$ did not have HCMV infections and eight of them $(24 \%)$ had bacterial infection. There was a high correlation with bacterial infections among CMV-positive patients ${ }^{(11)}$.

We found two cases were positive by HCMV IgM and real-time PCR and 65 
Martín-Dávila et al.(2004) showed that The sensitivity, specificity, positive 203 predictive value (PPV) and negative predictive value (NPV) of real-time PCR were 204 78\%, 77\%, 47\%, 89\% respectively ${ }^{(12) .}$ The study by Schmidt et al., (1995) for 205 diagnosis of HCMV infection after liver transplantation, showed that in a total of 30 206 patients, fourteen patients (46\%) were positive by PCR. The sensitivity and specificity 207 of PCR was $100 \%$ and $76 \%$, respectively. However, for the HCMV IgM, the 208 sensitivity was only $66 \%$, and the specificity was $84 \%$.The demonstration of HCMV 209 IgM antibodies is of little practical help as the antibody response develops too late in 210 relation to infection ${ }^{(13)}$ Patel et al., (1994) reported that the sensitivity of PCR in the diagnosis of symptomatic HCMV infection in liver transplant recipients was $100 \%$,the specificity was $57 \%$ and the positive predictive value was $50 \%{ }^{(14)}$

In this study, there was no significant differences between patients with positive HCMV infection versus those with negative HCMV infection as regards clinical data ( $>00.05)$. Gastroenteritis (50\%), hepatitis (70\%) and fever (80\%) showed significant differences between positive cases versus control subjects $(\mathrm{p}=0.033,0.003$, 0.001 respectively). Pneumonitis (20\%) did not differ significantly between positive cases and control subjects. The classic illness caused by HCMV after transplantation is manifested by fever, bone marrow suppression, and Invasive diseases, which had been traditionally categorized either as HCMV syndrome. The most common organ system involved during HCMV disease is the gastrointestinal tract (in the form of HCMV gastritis, esophagitis, enteritis, and colitis), accounting for over $70 \%$ of tissue invasive HCMV disease cases in solid organ transplant recipients ${ }^{(15) .}$ The clinical indications for liver transplantation did not show any significant differences between patients with positive HCMV infection versus those with negative infection or with control group $(\mathrm{p}>0.05)$.

The similarity of clinical indications for liver transplantation between the studied patients and control group might explain the insignificant difference between these groups. The incidence of recurrent $\mathrm{HCV}$ was higher in patients with active HCMV infection versus control $40.0 \%$ and $12.1 \%$ in negative HCMV ( $p=0.046)$ respectively. In addition, patients with active HCMV infection showed higher incidence of acute rejection compared to control group (50.0\% and $24.2 \% \%)$ 
reported that the incidence of HCMV induced cirrhosis was 50\% compared to $11 \%$ in

non-infected patients $(16,17)$. HCMV infection has been associated with an increased

risk for severity of $\mathrm{HCV}$ recurrence and this might be related to immunosuppression

showed that, recurrent HCV infection after LDLT occurred in $55.6 \%$ of the patients with HCMV infection and $49.8 \%$ of patients without HCMV infection ${ }^{(16) .}$

The HCMV positive cases in comparison with control group showed elevated serum bilirubin (total and direct) and serum GGT ( $\mathrm{p}=0.002,0.001,0.009)$ respectively, and elevated serum ALP and hyperglycemia ( $p=0.093,0.071)$ respectively. In significant difference $(\mathrm{p}=0.0503,0.066)$ respectively. In multivariable analysis, increased risk for HCMV infection was evident in patients with lower model for endstage liver disease $(\mathrm{MELD})$ score $(\mathrm{P}=0.025)$, lower total bilirubin $(\mathrm{P}=0.014)$, and longer operative time $(\mathrm{P}=0.038)^{(9)}$.

\section{Summary and conclusion}

Out of 76 patients, $74(97.36 \%)$ patients were IgG seropositive and three patients (3.9\%) were HCMV IgM seropositive. Real-time PCR was positive in 10 patients (13.2\%). In this study, two cases were positive by HCMV IgM and real-time PCR and 65 were negative by both techniques. The sensitivity, specificity, positive predictive value and negative predictive value of ELISA IgM for HCMV were (20.0\%, $98.5 \%, 66.7 \%$ and $89.0 \%$ ) respectively. The incidence of active HCMV by real-time 258 PCR in studied group I= 13.2\%. Gastroenteritis (50\%), hepatitis (70\%) and fever (80\%) showed significant differences between positive cases versus control subjects ( $\mathrm{p}=0.033,0.003,0.001$ respectively). The incidence of recurrent HCV was higher in 
differences $(\mathrm{p}=0.038)$. Mild decrease in hemoglobin concentration and mild elevation

1- Zuckerman R and Wald A (2009): Herpes simplex virus infections in solid organ transplant recipients. Am J Transplant; 4(Suppl 9): S104-S107.

2- Efstathiou S, Gompels UA, Craxton MA, Honess RW, Ward K. (1988): 276 DNA homology between a novel human herpesvirus (HHV-6) and human 277 cytomegalovirus. Lancet.; 1:63-64

3- Ho M (1990): Epidemiology of cytomegalovirus infections. Rev. Infect. Dis.; 12 (Suppl 7 ): S701-S710.

4- Razonable RR and Paya CV (2003): Herpesvirus infections in transplant 281 recipients: current challenges in the clinical management of cytomegalovirus 282 and Epstein-Barr virus infections. Herpes.; 10: 60-65.

5- Dahiya D, Lee CF, Chan KM, Wu TJ, Chou HS, Cheng SS, Lee WC. 284 (2011): short-term preemptive treatment for cytomegalovirus infection in 285 seropositive patients after liver transplantation. J Hepatobiliary Pancreat Sci.; 286 18: $32-38$.

6- Eid AJ, Arthurs SK, Deziel PJ, Wilhelm MP. (2010): Clinical predictors of relapse 288 after treatment of primary gastrointestinal cytomegalovirus disease in solid 289 organ transplant recipients. Am J Transplant.; 10: 157-161.

7- Jain A, Orloff M, Kashyap R, Lansing K, Betts R, Mohanka R, Menegus 291 M, Ryan C, Bozorgzadeh A. (2005): Does valganciclovir hydrochloride 292 (valcyte) provide effective prophylaxis against cytomegalovirus infection in 293 liver transplant recipients? Transplant Proc 2005; 37: 3182-3186.

8- Wadhawan M, Gupta S, Goyal N, Vasudevan R K, Makki K, Dawar R, 295 Sardana R, Lal N and Kumar A. (2012): Cytomegalovirus infection: its incidence and management in cytomegalovirus-seropositive living related 296 liver transplant recipients: a single-center experience. Liver Transpl. 12:14481455 .

9- Katsolis JG, Bosch W, Heckman MG, Diehl NN, Shalev JA, Pungpapong S, Gonwa 300 TA, Hellinger WC. (2013): Evaluation of risk factors for cytomegalovirus 
infection and disease occurring within 1 year of liver transplantation in high-

302 risk patients. Transpl Infect Dis.;15(2):171-80.

10- Garbinoa J, Romandb J-A, Pittetc D, Giostrad E, Menthae G, Suter P. 304 (2005): Infection and rejection in liver transplant patients: a 10-year Swiss 305 single-centre experience.SWISS MED WKLY 2005;135:587-593.

11-Milan A, Sampaio AM, Guardia AC, .Pavan CR, Andrade PD, Bonon 307 SHA, Costa SCB, Ataíde EC, Boin IFSF, Stucchi RSB. (2013): 308 Identification of bacterial infections and clinical manifestation associated with 309 cytomegalovirus in liver transplantation patients. Transplant Proc.: 310 45(3):1130-1132.

12- Martín-Dávila P1, Fortún J, Gutiérrez C, Martí-Belda P, Candelas A, Honrubia 312 A, Barcena R, Martínez A, Puente A, de Vicente E, Moreno S. (2004): Analysis of a quantitative PCR assay for CMV infection in liver transplant recipients: an 313 intent to find the optimal cut-off value. J Clin Virol. 33(2):138-44.

13-Schmidt CA, Oettle H, Peng R, Neuhaus P, Blumhardt G, Lohmann R, Wilborn F, 316 Osthoff K, Oertel J, Timm H, Schmidt CA. (1995): Comparison of polymerase chain reaction from plasma and buffy coat with antigen detection and 318 occurrence of immunoglobulin $\mathrm{M}$ for the demonstration of cytomegalovirus infection after liver transplantation. Transplantation.; 59(8):1133-8.

14- Patel R, Smith TF, Espy M, Wiesner RH, Krom RA, Portela D, Paya CV. 321 (1994): Detection of Cytomegalovirus DNA in Sera of Liver Transplant Recipients. J Clin Microbiol.; 6: 1431-1434.

15- Fica A, Cervera C, Pérez N, Marcos MA, Ramírez J, Linares L, Soto G, Navasa Immunohistochemically proven cytomegalovirus end-organ disease in solid organ transplant patients: clinical features and usefulness of conventional diagnostic tests. Transpl Infect Dis.; 9: 203-210.

16-Singh N, Wannstedt C, Keyes L, Wagener M M, Gayowski T, Cacciarelli TV. 329 (2005): Indirect outcomes associated with cytomegalovirus (opportunistic infections, hepatitis C virus sequelae, and mortality) in liver-transplant recipients with the use of preemptive therapy for 13 years. Transplantation.; 79: 1428-1434. 
17- Rosen HR, Chou S, Corless CL, Gretch DR, Flora KD, Boudousquie A, Orloff 334

SL, Rabkin JM, Benner KG. (1997): Cytomegalovirus viremia: risk factor for 335

allograft cirrhosis after liver transplantation for hepatitis C. Transplantation.; 336

64(5):721-726. 337

18- Wiesner RH, Sorrell M and Villamil F (2003): Report of the first 338

International Liver Transplantation Society expert panel consensus conference 339

on liver transplantation and hepatitis C. Liver Transpl.; 9:S1-S9. 340 
Table I: Thermal profile of HCMV DNA real-time PCR ((Applied Biosystems Inc., Foster City, CA)

\begin{tabular}{|c|c|c|c|}
\multirow{2}{*}{ Steps } & Taq Activation & \multicolumn{2}{|c|}{ PCR ( 45 cycles ) } \\
\cline { 2 - 4 } & Hold & Denaturation & Annealing \& Extension \\
\hline Temperature & $95^{\circ} \mathrm{C}$ & $95^{\circ} \mathrm{C}$ & $55^{\circ} \mathrm{C}$ \\
\hline Duration & $10: 00 \mathrm{~min}$ & $15 \mathrm{sec}$ & $01: 00 \mathrm{~min}$ \\
\hline
\end{tabular}


Table (2): Age and sex distribution in all studied subjects.

\begin{tabular}{|l|l|c|c|c|}
\hline \multicolumn{2}{|c|}{} & $\begin{array}{c}\text { Group I } \\
(\mathbf{n = 7 6})\end{array}$ & $\boldsymbol{p}$ \\
\hline \multirow{2}{*}{ Age (years) } & $51.14 \pm 7.116$ & $49.90 \pm 6.740$ & 0.602 \\
\hline \multirow{2}{*}{ Sex } & Males & $68(89.5 \%)$ & $8(80.0 \%)$ & \multirow{2}{*}{0.328} \\
\cline { 2 - 5 } & Females & $8(10.5 \%)$ & $2(20.0 \%)$ & \\
\hline
\end{tabular}

P: significance between total cases versus control.

Table (3): Time-related HCMV infection in living-donor liver transplanted patients.

\begin{tabular}{|l|c|c|}
\hline & $\begin{array}{c}\text { Group I } \\
(\mathbf{n = 7 6})\end{array}$ & $\begin{array}{c}\text { Group II } \\
(\mathbf{n = 1 0})\end{array}$ \\
\hline HCMV & $2.58 \pm 5.347$ & $1.6 \pm 0.699$ \\
\hline
\end{tabular}


Table (4): Clinical data of the studied patients.

\begin{tabular}{|l|c|c|c|c|c|}
\hline \multicolumn{1}{|c|}{$\begin{array}{c}\text { Underlying liver } \\
\text { disease }\end{array}$} & \multicolumn{2}{c|}{$\begin{array}{c}\text { Group I } \\
\text { (n=76) }\end{array}$} & \multicolumn{2}{c|}{$\begin{array}{c}\text { Group II } \\
(\mathbf{n = 1 0})\end{array}$} & P \\
\cline { 2 - 5 } & No. & $\%$ & No. & $\%$ & \\
\hline Gastroenteritis & 32 & 42.1 & 0 & 0 & 0.011 \\
\hline Hepatitis & 43 & 56.6 & 0 & 0 & 0.001 \\
\hline Fever & 53 & 69.7 & 0 & 0 & $<0.001$ \\
\hline Pneumonitis & 4 & 5.3 & 0 & 0 & 1.000 \\
\hline
\end{tabular}

P: significance between total cases versus control.

Table (5): HCMV detection rate by different methods in studied cases $(n=76)$.

\begin{tabular}{|c|c|c|c|c|c|c|}
\hline & \multicolumn{2}{|c|}{ Group I $(n=76)$} & \multicolumn{2}{|c|}{$\begin{array}{l}\text { Group II } \\
(n=10)\end{array}$} & \multirow[b]{2}{*}{$P$} \\
\hline & & No & $\%$ & No & $\%$ & \\
\hline \multirow{2}{*}{$\begin{array}{l}\text { CMV IgG } \\
\text { (ELISA) }\end{array}$} & Positive & 74 & 97.4 & 10 & 100.0 & \multirow[b]{2}{*}{1.000} \\
\hline & Negative & 2 & 2.6 & 0 & 0 & \\
\hline \multirow{2}{*}{$\begin{array}{l}\text { CMV IgM } \\
\text { (ELISA) }\end{array}$} & Positive & 3 & 3.9 & 0 & 0 & \multirow[b]{2}{*}{1.000} \\
\hline & Negative & 73 & 96.1 & 10 & 100.0 & \\
\hline \multirow{2}{*}{$\begin{array}{l}\text { CMV DNA } \\
\text { Real time } \\
\text { PCR }\end{array}$} & Positive & 10 & 13.2 & 0 & 0 & \multirow[b]{2}{*}{0.588} \\
\hline & Negative & 66 & 86.8 & 10 & 100.0 & \\
\hline
\end{tabular}

P: significance between total cases versus control. 
Table (6): Sensitivity, specificity, positive and negative predictive values of ELISA IgM for detection of HCMV in comparison PCR.

\begin{tabular}{|c|c|c|c|c|c|c|c|c|c|}
\hline \multirow{2}{*}{\multicolumn{2}{|c|}{ Method of Detection }} & \multicolumn{2}{|c|}{$\begin{array}{c}\text { Negative } \\
\text { HCMV } \\
(66)\end{array}$} & \multicolumn{2}{|c|}{$\begin{array}{c}\text { Positive } \\
\text { HCMV } \\
(10) \\
\end{array}$} & \multirow[t]{2}{*}{$\begin{array}{c}\text { Sensitivity } \\
(\%)\end{array}$} & \multirow[t]{2}{*}{$\begin{array}{c}\text { Specificity } \\
(\%)\end{array}$} & \multirow[t]{2}{*}{$\begin{array}{l}\text { PPV } \\
(\%)\end{array}$} & \multirow[t]{2}{*}{$\begin{array}{l}\text { NPV } \\
(\%)\end{array}$} \\
\hline & & No & $\%$ & No & $\%$ & & & & \\
\hline \multirow{2}{*}{$\begin{array}{l}\text { CMV IgM } \\
\text { (ELISA) }\end{array}$} & $\begin{array}{l}\text { Positive } \\
(n=3)\end{array}$ & 1 & 1.5 & 2 & 20.0 & \multirow[t]{2}{*}{20.0} & \multirow[t]{2}{*}{98.5} & \multirow[t]{2}{*}{66.7} & \multirow{2}{*}{89.0} \\
\hline & $\begin{array}{l}\text { Negative } \\
(n=73)\end{array}$ & 65 & 98.5 & 8 & 80.0 & & & & \\
\hline
\end{tabular}

PPV: Positive predictive value, NPV: Negative predictive value.

Table (7): Clinical data of HCMV infection in-group I (n=76).

\begin{tabular}{|l|c|c|c|c|c|c|c|}
\hline \multirow{2}{*}{\multicolumn{1}{c|}{$\begin{array}{c}\text { Clinical } \\
\text { presentations }\end{array}$}} & \multicolumn{2}{c|}{$\begin{array}{c}\text { Negative } \\
\text { HCMV } \\
(\mathbf{6 6})\end{array}$} & \multicolumn{2}{c|}{$\begin{array}{c}\text { Positive } \\
\text { HCMV } \\
(\mathbf{1 0})\end{array}$} & \multicolumn{2}{c|}{$\begin{array}{c}\text { Group II } \\
(\mathbf{n = 1 0})\end{array}$} & \multirow{2}{*}{$\boldsymbol{P}$} \\
\cline { 2 - 9 } & No. & $\%$ & No. & $\%$ & No. & $\%$ & \\
\hline Gastroenteritis & 27 & 40.9 & 5 & 50.0 & 0 & 0 & 0.033 \\
\hline Hepatitis & 36 & 54.5 & 7 & 70.0 & 0 & 0 & 0.003 \\
\hline Fever & 45 & 68.2 & 8 & 80.0 & 0 & 0 & 0.001 \\
\hline Pneumonitis & 2 & 3.0 & 2 & 20.0 & 0 & 0 & 0.474 \\
\hline
\end{tabular}

P: significance between total cases versus control. 
Table (8): Relationship between clinical indications for liver transplantation to HCMV infection in all patients $(n=76)$ versus control $(n=10)$.

\begin{tabular}{|l|c|c|c|c|c|c|c|}
\hline \multicolumn{1}{|c|}{ Indications } & \multicolumn{2}{c|}{$\begin{array}{c}\text { Negative } \\
\text { HCMV } \\
(\mathbf{6 6})\end{array}$} & \multicolumn{2}{c|}{$\begin{array}{c}\text { Positive } \\
\text { HCMV } \\
(\mathbf{1 0})\end{array}$} & $\begin{array}{c}\text { Group III } \\
(\mathbf{n = 1 0})\end{array}$ & $P$ \\
\cline { 2 - 9 } & No. & $\%$ & No. & $\%$ & No. & $\%$ & $0.801^{\#}$ \\
\hline HCV liver cirrhosis & 44 & 66.7 & 6 & 60.0 & 7 & 70.0 & 1.000 \\
\hline HCC liver & 15 & 22.7 & 3 & 30.0 & 3 & 30.0 & 0.693 \\
\hline HBV liver cirrhosis and HBV & 1 & 1.5 & 0 & 0 & 0 & 0 & 1.000 \\
\hline $\begin{array}{l}\text { HCV cirrhosis } \\
\text { Cryptogenic liver cirrhosis }\end{array}$ & 2 & 3.0 & 0 & 0 & 0 & 0 & 1.000 \\
\hline Budd-Chiari syndrome & 2 & 3.0 & 1 & 10.0 & 0 & 0 & 1.000 \\
\hline Autoimmune liver cirrhosis & 1 & 1.5 & 0 & 0 & 0 & 0 & 1.000 \\
\hline
\end{tabular}

HCV: Hepatitis $\mathrm{C}$ virus.

HCC: Hepatocellular carcinoma.

HBV: Hepatitis B virus

P: significance between positive cases versus control. 
Table (9): Comparison between HCMV infection and other laboratory data in group I ( $\mathbf{n = 7 6 )}$ versus control (group II: $\mathbf{n = 1 0}$ ).

\begin{tabular}{|c|c|c|c|c|c|c|c|c|c|}
\hline \multirow{2}{*}{\multicolumn{2}{|c|}{ Laboratory data }} & \multicolumn{2}{|c|}{$\begin{array}{c}\text { Negative HCMV } \\
(n=66)\end{array}$} & \multicolumn{2}{|c|}{$\begin{array}{c}\text { Positive HCMV } \\
(n=10)\end{array}$} & \multicolumn{2}{|c|}{$\begin{array}{c}\text { Group II } \\
(\mathbf{n}=10)\end{array}$} & \multirow[t]{2}{*}{$\boldsymbol{P}$} & \multirow[t]{2}{*}{$P^{*}$} \\
\hline & & Mean & SD & Mean & SD & Mean & SD & & \\
\hline \multicolumn{2}{|c|}{ Albumin (g/dl) } & 3.55 & 0.49 & 3.66 & 0.62 & 3.83 & 0.440 & 0.512 & 0.490 \\
\hline \multirow{2}{*}{ 党 } & $\begin{array}{l}\text { Total } \\
\text { (mg/dl) }\end{array}$ & 2.93 & 5.92 & 2.19 & 1.02 & 0.99 & 0.179 & 0.697 & 0.002 \\
\hline & $\begin{array}{l}\text { Direct } \\
(\mathrm{mg} / \mathrm{dl})\end{array}$ & 1.85 & 4.91 & 1.31 & 0.80 & 0.15 & 0.053 & 0.729 & 0.001 \\
\hline \multicolumn{2}{|c|}{ ALT (U/ml) } & 50.26 & 94.79 & 28.20 & 11.72 & 26.90 & 6.707 & 0.467 & 0.764 \\
\hline \multicolumn{2}{|c|}{ AST (U/ml) } & 78.21 & 149.81 & 34.80 & 13.43 & 29.30 & 8.042 & 0.365 & 0.281 \\
\hline \multicolumn{2}{|c|}{ GGT (U/L) } & 1.52 .48 & 138.61 & 111.30 & 81.38 & 25.20 & 5.266 & 0.364 & 0.009 \\
\hline \multicolumn{2}{|c|}{ ALP (KAU) } & 11.33 & 9.18 & 8.70 & 2.54 & 11.50 & 4.301 & 0.373 & 0.093 \\
\hline \multicolumn{2}{|c|}{ Creatinine (mg / dl) } & 1.24 & 0.69 & 1.06 & 0.62 & 0.91 & 0.145 & 0.450 & 0.464 \\
\hline \multicolumn{2}{|c|}{$\begin{array}{l}\text { F.B.Glucose (mg / } \\
\text { dl) }\end{array}$} & 138.83 & 61.09 & 140.00 & 64.52 & $\begin{array}{c}100.7 \\
0\end{array}$ & 6.056 & 0.956 & 0.071 \\
\hline \multicolumn{2}{|c|}{ CRP (mg / L) } & 41.95 & 53.92 & 38.40 & 45.56 & 3.50 & 1.080 & 0.844 & 0.038 \\
\hline \multicolumn{2}{|c|}{ TLC $\left(\mathrm{X10}^{9} / \mathrm{I}\right)$} & 8.25 & 7.07 & 6.60 & 3.15 & 6.740 & 2.202 & 0.474 & 0.912 \\
\hline \multicolumn{2}{|c|}{ Hb (g/dl) } & 10.29 & 2.02 & 10.13 & 1.13 & $\begin{array}{c}11.27 \\
0\end{array}$ & 1.295 & 0.720 & 0.0503 \\
\hline \multicolumn{2}{|c|}{ Platelets $\left(\mathrm{X10}^{9} / \mathrm{I}\right)$} & 157.50 & 88.48 & 204.80 & 116.24 & $\begin{array}{c}165.0 \\
0\end{array}$ & $\begin{array}{c}68.32 \\
3\end{array}$ & 0.135 & 0.363 \\
\hline \multicolumn{2}{|l|}{ INR } & 1.28 & 0.63 & 1.31 & 0.38 & 1.060 & 0.070 & 0.897 & 0.066 \\
\hline
\end{tabular}

P: significance between total cases versus control.

$\mathrm{P}^{*}$ : significance between positive cases versus control. 
Table 10:

\section{Relationship of post-transplant complications to active HCMV in} group I $(n=76)$.

\begin{tabular}{|c|c|c|c|c|c|c|c|c|c|}
\hline \multirow{2}{*}{\multicolumn{2}{|c|}{ Complications }} & \multicolumn{2}{|c|}{$\begin{array}{c}\text { Negative } \\
\text { HCMV } \\
(66)\end{array}$} & \multicolumn{2}{|c|}{$\begin{array}{c}\text { Positive } \\
\text { HCMV } \\
\text { (10) }\end{array}$} & \multicolumn{2}{|c|}{$\begin{array}{l}\text { Group II } \\
(\mathbf{n}=10)\end{array}$} & \multirow[t]{2}{*}{$P$} & \multirow[t]{2}{*}{$P^{*}$} \\
\hline & & No & $\%$ & No & $\%$ & No & $\%$ & & \\
\hline \multirow{2}{*}{ Acute rejection } & Early & 16 & 24.2 & 5 & 50.0 & 0 & 0 & 0.128 & 0.033 \\
\hline & Late & 5 & 7.6 & 0 & 0 & 0 & 0 & 0.368 & - \\
\hline \multicolumn{2}{|l|}{ Recurrent HCV } & 8 & 12.1 & 4 & 40.0 & 0 & 0 & 0.046 & 0.087 \\
\hline \multicolumn{2}{|l|}{ Recurrent HCC } & 4 & 6.1 & 0 & 0 & 0 & 0 & 0.424 & - \\
\hline \multicolumn{2}{|c|}{ Biliary complications } & 12 & 18.2 & 1 & 10.0 & 0 & 0 & 0.522 & 1.000 \\
\hline \multicolumn{2}{|c|}{ Portal vein stenosis } & 7 & 10.6 & 0 & 0 & 0 & 0 & 0.584 & - \\
\hline \multicolumn{2}{|c|}{$\begin{array}{l}\text { Renal impairment, toxicity and } \\
\text { failure }\end{array}$} & 11 & 16.7 & 0 & 0 & 0 & 0 & 0.341 & - \\
\hline \multicolumn{2}{|l|}{ DM } & 5 & 7.6 & 0 & 0 & 0 & 0 & 0.368 & - \\
\hline \multicolumn{2}{|l|}{ HTN } & 6 & 9.1 & 0 & 0 & 0 & 0 & 0.320 & - \\
\hline \multicolumn{2}{|c|}{ Pneumonia and pleural effusion } & 4 & 6.1 & 0 & 0 & 0 & 0 & 0.424 & - \\
\hline \multicolumn{2}{|l|}{ Other infections } & 8 & 12.1 & 1 & 10.0 & 0 & 0 & 0.847 & 1.000 \\
\hline \multicolumn{2}{|l|}{ Pancytopenia } & 2 & 3 & 1 & 10.0 & 0 & 0 & 0.349 & 1.000 \\
\hline
\end{tabular}

HCV: Hepatitis C virus.

HCC: Hepatocellular carcinoma.

DM: Diabetes Mellitus

HTN: Hypertension

P: significance between positive cases versus control.

$\mathrm{p}^{*}$ : significance between positive cases versus negative cases. 


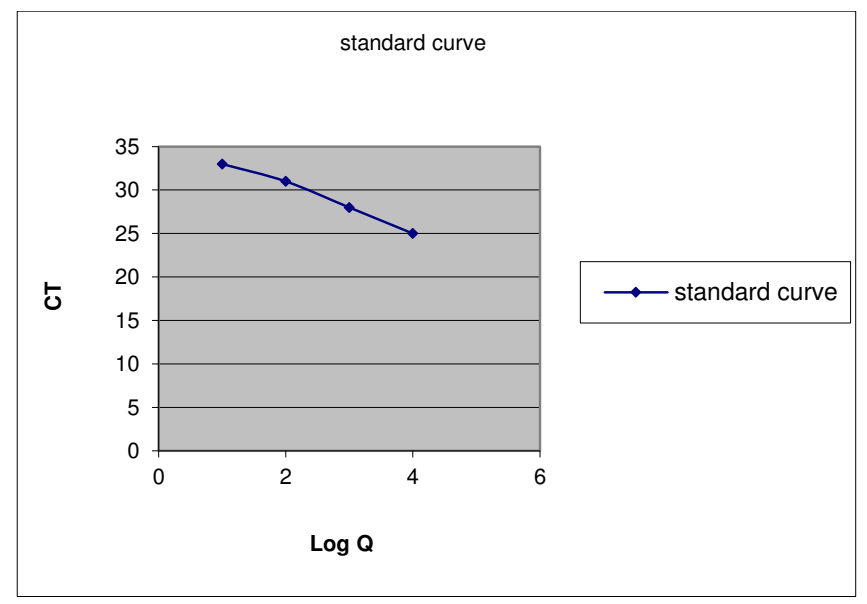

Figure I: Standard curve of quantitation of HCMV by real-time PCR 